Management, Procurement and Law Volume 169 Issue MP2

Late disputes and the NEC3 Engineering and Construction Contract

Ndekugri
Proceedings of the Institution of Civil Engineers

Management, Procurement and Law 169 April 2016 Issue MP2

Pages 65-76 http://dx.doi.org/10.1680/jmapl.15.00037

Paper 1500037

Received 18/07/2015 Accepted 16/12/2015

Published online 01/03/2016

Keywords: contracting/contracts \& law/disputes \& arbitration

\title{
Late disputes and the NEC3 Engineering and Construction Contract
}

Issaka Ndekugri BSC, LLB, MSC, PhD, MRICS, MCIOB

Professor, Faculty of Science and Engineering, University of

Wolverhampton, Wolverhampton, UK (i.e.ndekugri@wlv.ac.uk)

Surveys show growing use of the third edition of the New Engineering Contract (NEC3) family of contracts. One of the reasons for project owners' choice of the NEC3 Engineering and Construction Contract is the avoidance of the risk of claims and disputes long after project completion. In several cases not involving NEC3 contracts, UK courts have been presented with difficult questions concerning adjudication after project completion and delayed reference of adjudicated disputes to the applicable final tribunal. This paper critically examines these questions, the courts' answers to them and their implications for the NEC3 family of contracts. It concludes that the drafters of future editions of the NEC3 Engineering and Construction Contract should consider provisions targeted at: ensuring that the test of awareness for the purposes of the clause 61.3 time-bar is on an objective basis; conclusive evidence clauses that impose a disincentive against seriously delayed challenges to assessment of compensation events and payment; and providing that the decision of an adjudicator becomes finally binding if the dispute decided is not referred to the tribunal within a stated period.

\section{Introduction}

The general approach in traditional contracts to the assessment of the impact of change events, certification and payment has been one of provisional decisions on these matters based on rough measurements of work completed and conservative estimates of impacts to date. There are then periodic retrospective reviews of the decisions after accurate measurements and full knowledge of the actual impact of the change events. Interim payments can therefore be certified on time and without expending the full staff resources necessary to produce accurate measurements and valuations. Approximate measurements, valuations and assessments are replaced with accurate figures produced as they become available. Final decisions on the impact of change events are not taken based on forecasts of their future effects.

It has therefore been a long-standing tradition in construction contracts that the payment certificates and the valuations on which they are based are only provisional until after the completion of the works. There is usually a period of 6-12 months after the works are taken over, referred to by a variety of terms such as Maintenance Period, Defects Liability Period, Defects Correction Period and Rectification Period, during which the contractor is entitled to be asked back to make good any work outstanding at handover or defects that appear thereafter. The rectification period label is used hereafter. The contract administrator is usually required to certify completion of the task of making good defects.

It is to be noted that the NEC3 Engineering and Construction Contract (ECC) uses the concept of a defect correction period but in a completely different context, details of which are not material to the purpose of this paper. During the defects correction period in its traditional context, the contract administrator, on his or her own initiative or at the request of the contractor, often reviews valuation of variations, assessment of price adjustment for fluctuation of prices after the award of the contract and assessments of money and extension of time claims. The contractor may also bring up outstanding variations or raise new claims for time and/or money at this stage.

Further payment certificates have to be issued to implement more accurate valuations, decisions on disputes and the contract administrator's decisions on new claims. Such certification proceeds in parallel with the drawing up of the final financial settlement of the project, commonly referred to as final accounts. The post-handover procedures culminate in the issue of a final certificate stating the adjusted contract price for the project and the resulting final payment instalment to be made. In contrast to earlier certificates, the final certificate may state that the payment is to be made by the contractor to the employer where there had been overpayment by the employer because of overcertification resulting from the earlier provisional assessments.

Project owners have an interest in achieving financial closure, thus minimising any outstanding risk of having to answer to claims and disputes long after project completion. The approach in traditional contracts to achieving such closure has been to have provisions curtailing the contractor's right to start new claims or treating the final certificate and the accompanying final accounts 
as conclusive evidence in any subsequent proceedings that full effect has been given to the contractor's financial and extension of time entitlements under the contract. The leading example of this approach is clause 1.9 of the 2011 edition of the Joint Contracts Tribunal (JCT) Standard Building Contract (JCT2011) (JCT, 2011). The Fidic Red Book (Fidic, 1999) adopts a time-bar to all contractor claims (see clause 20.1).

As is now well known, the NEC3 family of contracts uses the concepts of compensation events and assessment of compensation events, where traditional contracts use claims, valuation of variations and interim valuations. It is in relation to the status of certificates and the assessment of compensation events that professionals brought up on traditional contracts, and without remedial training on the New Engineering Contract (NEC) philosophy on certification and payment, can easily get things completely wrong. The first difference to note is that all payment certificates under the price-based ECC contracts are final in the sense that the underlying decisions are not provisional.

Also, in contrast to traditional practice, the assessment of compensation events must have a prospective element where the impact of the event is still to play itself out. The assessment is based on forecast impact where the impact is unfolding or is still to be experienced. Contrary to basic canon of the traditional contracting approach, the assessment is not to be reviewed on the grounds that the impact actually experienced is different from the forecast (clause 65.2). Both parties accept the risk of the difference. Changes are made only to reflect correction of mistakes in the decisions, the adjudicators' decisions and the assessments of compensation events rather than the substitution of final figures for initial figures generally treated as only provisional. The correction of undercertification carries interest (clause 51.3).

In a number of cases the court has been presented with difficult questions about adjudication after completion of the contract works and the subsequent determination of the adjudicated disputes by the applicable final tribunal. These cases therefore have direct implications for some of the JCT contracts used on the projects from which the disputes arose. The JCT is likely to take account of these cases in future editions. None of the cases arose from a project procured using the NEC contracts. The purpose of this paper is to examine these questions and the answers to them and their implications for the NEC3 family of contracts.

The paper is structured into eight parts. The most frequently used dispute resolution method in the UK other than negotiation is adjudication under the Housing Grants, Construction and Regeneration Act 1996 (1996) - referred to hereafter as the HGCRA. Knowledge of the provisions in the HGCRA and the procedure and terminologies of current adjudication practice is essential to understanding some of the issues considered in the paper. For these reasons, the law and the practice of adjudication are outlined in Section 2. The question of when it can be said that adjudication proceedings have been validly started is very important not only because of the general need to start the proceedings within the applicable limitation period but also because time limits are specified in some contracts for the commencement of such proceedings. For this reason, judicial decisions on this question are examined in Section 3.

Section 4 analyses case law on the timetable within which court or arbitration proceedings may be started by the unsuccessful party to an adjudication to challenge the decision and to recover payment made pursuant to it. As the impact of change events and the payment procedures are at the heart of claims and disputes, the NEC3 ECC provisions on these matters are outlined in Sections 5 and 6. Section 7 examines the implications of the decisions for ECC contracts. Finally, conclusions and recommendations for practice are provided.

For ease of reading, all NEC contract terms are set in lower-case, non-italic type and their meanings (unless stated otherwise) are intended to be as defined and/or identified in the relevant NEC3 contract.

\section{Outline of the law and the procedure of adjudication under the HGCRA}

Section 108(1) of the HGCRA requires every qualifying construction contract to provide that a party to it has a right, at any time, to refer any dispute under it for resolution by adjudication. The contractual adjudication procedure must meet, as a minimum, nine procedural ingredients identified in sections 108(2)-(4).

The legislation has been ring-fenced for application to only construction contracts as defined in sections 104 and 105. Section 108(5) provides that, where a qualifying construction contract does not comply with the mandatory contractual content, the adjudication procedural rules in a scheme for construction contracts (SCC) implemented by statutory instrument (Statutory Instrument 1998 No. 649 (HMG, 1998a)) apply regardless of the intention of the parties to the contract. Part I of this document sets out adjudication procedural rules which include the nine mandatory procedural elements specified by the HGCRA.

A separate SCC was developed for Scotland (Statutory Instrument 1998 No. 687 (HMG, 1998b)). The two schemes are essentially the same, the differences having been limited to those necessary to reflect the special features of Scottish legal systems and terminologies. Any reference hereafter to the SCC is to that applicable to England and Wales. The HGCRA has been amended by part 8 of the Local Democracy, Economic Development and Construction Act 2009 (2009) based on experience of adjudication under the original legislation.

A fundamental feature of adjudication as a method of resolving construction disputes is that, pending final determination of the dispute by litigation or arbitration, the decision of the adjudicator is binding on the parties, who must comply with it. For example, if a dispute arises as to how much a project owner should pay the 
contractor or the designer (an architect and/or engineer) for their work done, either party may refer it to an adjudicator, who must make a decision within $28 \mathrm{~d}$ rather than months or even years that litigation and arbitration of these types of disputes often take.

The parties must comply with the adjudicator's decision, although they retain the right to refer the same dispute to arbitration or litigation. For example, if an adjudicator orders payment to be made by one party to the other, that decision must be complied with even if the paying party believes the adjudicator's determination to be wrong. However, if the final tribunal (the court or an arbitral tribunal) decides otherwise, the recipient must make appropriate repayment.

Most adjudications are preceded by a period during which the parties engage in exchanges about a problem that culminate in a demand or an assertion by one party to which the other party responds in a way from which it may be inferred that a dispute has crystallised (Ndekugri and Russell, 2006). Either party may then refer the dispute to adjudication. The first step towards such a reference is to serve a document commonly referred to as the notice of adjudication. Within $7 \mathrm{~d}$ after the service of this notice, an adjudicator must be appointed and the dispute referred to her/ him in accordance with the relevant procedures specified in the contract.

The adjudicator may already be specified in the contract. In the absence of such a specified adjudicator, the parties may agree to an individual to be appointed as adjudicator. Most contracts and the SCC provide for an adjudicator nominating body (ANB) to which the parties may apply to nominate an individual for appointment as adjudicator should they fail to make a consensual appointment. It is common practice for the applicable ANB to be specified in the contract.

\section{Dispute resolution timetable and contractual conclusivity provisions}

Clause 30.9.1 of the 1998 edition of the JCT Standard Building Contract (JCT98) (JCT, 1998) provided that the final certificate was to have effect in relevant litigation or arbitration proceedings as conclusive evidence that all claims by the contractor had been considered under the terms of the contract and that the final adjustment of the contract price required under the contract was reflected in it. An exception to such conclusiveness of the final certificate was stated in clause 30.9.3 in these terms

If any adjudication, arbitration or other proceedings have been commenced by either Party within 28 days after the Final Certificate has been issued, the final certificate shall have effect as conclusive evidence as provided in clause 30.9.1 save only in respect of all matters to which those proceedings [author's emphasis] relate.

In Tracy Bennett v. FMK Construction Ltd [2005], which arose from a contract incorporating the JCT98 form, the final certificate was issued on 11 March 2005. The contractor disputed it and, on
6 April 2005, served a notice of adjudication to refer the matter to adjudication. The appointment of the adjudicator and the referral were not achieved within $7 \mathrm{~d}$ of the notice as required by section 108(2)(b) of the HGCRA and paragraph 7(1) of the SCC.

The adjudicator resigned when his jurisdiction was challenged. On 22 April 2005, more than $28 \mathrm{~d}$ after the issue of the final certificate, the contractor served a fresh notice of adjudication to refer the same dispute. The same adjudicator was nominated by the ANB. One of the grounds on which the employer challenged the adjudicator's decision was that the contractual provisions on the conclusiveness of the final certificate had the effect that the second notice of adjudication was out of time as it had been served more than $28 \mathrm{~d}$ after the issue of the final certificate.

HHJ Havery QC made declarations upholding the decision. He explained that considering the use of the phrase those proceedings in the exception to the conclusiveness of the final certificate, not only did the exception apply to the dispute identified in the original notice but also it continued to apply to those issues even after the resignation of the adjudicator. A second point in the judge's analysis was that, in resigning, the adjudicator had become 'unavailable for some other cause' for which the contract expressly provided for reference to another adjudicator. $\mathrm{He}$ considered it irrelevant that the second nominee happened to have been the same adjudicator.

The second notice had therefore been 'surplusage'. A proposition common to both analytic approaches was that adjudication is properly started by the service of a notice of adjudication for the purpose of the exception to the conclusive evidence clause. HHJ Havery QC supported the proposition by drawing an analogy with arbitration for which there was established authority in Commercial Arbitration by Mustill and Boyd (1989) that arbitration proceedings are validly started on the service of a notice to refer to arbitration or a notice to concur in the appointment of an arbitrator. This principle has now been codified by section 14 of the Arbitration Act 1996 (1996). In other words, the appointment of an arbitrator is not a requirement.

In Cubitt Building \& Interiors Ltd v. Fleetglade Ltd [2006], the final certificate was issued on 24 August 2006 and received by the parties on 25 August. At 4:42 p.m., on 20 September 2006, Cubitt served notice to refer a payment dispute to adjudication. The adjudicator was appointed outside normal working hours on 27 September, the last day of the $7 \mathrm{~d}$ period. The referral notice could not be therefore served until 28 September 2006. Technically, the referral was therefore a day late. One of the grounds on which enforcement of the decision reached by the adjudicator was challenged was that the adjudicator had acted without jurisdiction on account of service of the referral notice outside the $7 \mathrm{~d}$ period.

HHJ Coulson QC, as he then was, stated that, although the $7 \mathrm{~d}$ period for the service of the referral notice was mandatory, it needed to be operated in a sensible and business-like way and 
that, therefore, it was an implied term of the contract that the referral notice could be validly served the following working day where, through no fault of the referring party, the adjudicator was appointed on the seventh day. The issue was whether the technical departures from the adjudication timetable had the effect of invalidating the decision. Whether the adjudication was properly started was not directly an issue.

That issue came before Carr $\mathrm{J}$ in Brighton University $\mathrm{v}$. Dovehouse Interiors Ltd [2014]. By a contract incorporating the JCT Intermediate Building Contract with Contractor's Design 2005 edition (JCT, 2005) with amendments, the university engaged the defendant to fit out its premises. The final certificate was issued on 9 December 2013. Clause 1.9.2 of the contract states

If any adjudication, arbitration or other proceedings are commenced by either Party before or not later than 28 days after the final certificate has been issued, the final certificate shall be conclusive evidence as provided in clause 1.9.1 save only in respect of the matters to which those proceedings relate.

The parties had agreed in writing to replace the $28 \mathrm{~d}$ with $66 \mathrm{~d}$. This meant that, for the purposes of the final certificate as conclusive evidence as stated, the last day was 14 February 2014. On 13 February 2014 the contractor served a notice of adjudication. It was common ground that the notice was received by the university the same day. Dovehouse had an adjudicator appointed by the Royal Institution of Chartered Surveyors (RICS). On 21 February the adjudicator resigned because he had determined from the referral notice that the correct ANB was the Royal Institute of British Architects (RIBA) and not the RICS. Dovehouse served a fresh notice of adjudication but, this time, seeking nomination from the RIBA. The university started the proceedings for a declaration that the final certificate had become conclusive evidence as stated in clause 1.9.2 and an injunction against continuation of the adjudication proceedings.

The main issue was whether the first notice had had the effect of starting adjudication proceedings for the purpose of the conclusive evidence clause. It was argued on behalf of the university that it did not have that effect for two reasons. First, it was argued that, in principle, adjudication proceedings cannot be properly started by the service of a notice of adjudication unless it leads to the service of a referral notice on a properly appointed adjudicator.

Applying Bennett v. FMK, the judge determined that the adjudication proceedings were started for the purpose of the conclusive evidence provision when the first notice was served and that it did not matter that it did not lead to a referral of the dispute. She also justified the proposition by analogy with arbitration. She added that making the appointment of an adjudicator and valid referral a precondition for valid commencement did not make commercial sense as the actions and the inactions of third parties over whom the parties had no control (e.g. the ANB and the individuals approached to take on the role of adjudicator) could always hold up the process.

A second argument against the adjudication was that, in any case, the notice of adjudication was too flawed with respect to its content and the address to which it had been served, to have had validity. The fact that two different addresses for the university were used on the contract was at the centre of the invalid notice argument: address A, which was stated as the university's address in the contract, and address B, another address of the university used by the parties on many occasions for various purposes and documents during the performance of the contract - for example, in minutes of meetings and interim payment certificates.

Paragraph 1(3) of the SCC requires the notice of adjudication to set out various matters, including 'the names and addresses of the parties to the contract (including, where appropriate, the addresses which the parties have specified for the giving of notices)'. Only address $\mathrm{B}$ was stated in the notice of adjudication. It was contended on behalf of the university that it was a mandatory requirement that address $\mathrm{A}$ was set out in the notice and that failure to do this had the effect that the notice was invalid.

The judge accepted that the SCC required address A to be set out in the notice but rejected that the omission to do this had the effect of invalidating it. She cited in support of her opinion Technology and Construction Court (TCC) decisions in which the court either refused to treat requirements of the SCC as mandatory or stated that any mandatory requirement needed to be operated in a sensible and business-like manner. It was not in dispute that the responding party was correctly identified in the notice and that the notice was also effectively served on it at the other address. In her opinion, it was not sensible to treat such notice as invalid just because of a technicality.

Clause 1.7.4 of the contract also contained this requirement of notices in general under the contract.

Subject to clause 1.7.2 and 1.7.4, any notice, communication or document may be given or served by any effective means and shall be duly given or served if delivered by hand or sent by pre-paid post to:

1. The recipient's address stated in the Contract Particulars, or to such other address as the recipient may from time to time notify to the sender; or

2. If no such address is then current, the recipient's last known principal business address or (where a body corporate) its registered or principal office.

It was common ground that the first notice of adjudication was not served at address A, the address stated in the contract. It was the position of the university that the omission to do this invalidated the notice. The judge doubted that clause 1.7.4 could be construed as imposing service at address A as a mandatory 
requirement of notices under the contract. She added that even if there was such a mandatory requirement, it did not have the effect of preventing the notice from taking effect as starting adjudication for the purpose of the saving provision.

It may therefore be concluded from the analysis in this section that the final certificate concept embodies two principles. First, the contract administrator's earlier determinations of periodic amounts due, their constituent elements and any accompanying extension of time are only provisional. This contractual approach may fairly be criticised for encouraging the practice of not fully dealing with the impact of change on price and time contemporaneously. Second, the final certificate generally takes effect as conclusive evidence in any subsequent proceedings that full and final effect has been given to the contractor's entitlement to payment and time under the contract or at common law.

The exception applies to only matters challenged before a specified period after the date of the certificate. It is therefore an issue whether, in departing from the traditional concept of a final certificate, there are clear provisions in the ECC that close the door to the parties, long after project completion, raising challenges to the determination of periodic payment and the assessments of related compensation events and referring the resultant disputes to adjudication.

\section{Final determination of the dispute}

The HGCRA contemplates proceedings being brought for a final determination of a dispute by arbitration or litigation after the same dispute has been referred to and decided in adjudication. Several TCC decisions make it clear that such proceedings may also be brought in parallel with the adjudication proceedings. However, exercising its case management responsibility, the court may set its timetable to allow completion of adjudication proceedings already underway before the court decision is due.

On a literal reading of section 108(1) of the HGCRA, the right to refer a dispute to adjudication includes reference even after expiry of the applicable limitation period under the contract but, as stated by Akenhead J at paragraph 27 of Aspect Contracts (Asbestos) Ltd v. Higgins Construction Plc [2013a], such a claim is doomed to failure on grounds of being statute-barred under section 5 of the Limitation Act 1980 (1980), which states

An action founded on simple contract shall not be brought after the expiration of six years from the date on which the cause of action accrued.

The question of the period within which the unsuccessful party in an adjudication may bring court or arbitration proceedings, as the case may be, for a refund of payment made pursuant to the adjudicator's decision has received different answers from TCC judges. At the heart of the question is the issue of what the cause of the action is that entitles the unsuccessful party in an adjudication to refer the same dispute to the final tribunal after compliance with the adjudicator's decision. In Letang v. Cooper [1965] Donaldson LJ described the 'cause of action' concept as 'simply a factual situation the existence of which entitles one person to obtain from the court a remedy against another person'. It is uncontroversial that, in an action for damages in contract, the cause of action is the breach of contract relied on.

In Jim Ennis Construction Ltd v. Premier Asphalt Ltd [2009], Ennis, a roadworks subcontractor on a supermarket development project, in April 2002, sub-subcontracted the road surfacing component to Premier. As the sub-subcontract did not have any express provision for adjudication, the SCC applied. Ennis had the surfacing work removed because it had been rejected by the main contractor on quality grounds. Premier replaced the surfacing and claimed about $£ 16800$ for the replacement works in its final payment application submitted on 17 December 2002. Ennis did not only reject this claim but also deducted some $£ 38600$ from Premier’s final account for delays allegedly caused by Premier.

For whatever reason, Premier did nothing about this problem until September 2008, nearly 6 years later, when it referred it to adjudication. On 13 November 2008 the adjudicator made a decision ordering payment to Premier. Ennis complied with the decision and initiated legal proceedings in April 2009 for a final determination of the dispute. Premier applied to strike out the proceedings on the grounds that they were statute-barred. The parties were in agreement that the court should determine the limitation question as a preliminary issue.

HHJ Stephen Davies QC started his analysis of the relevant issues by referring to section 108(3) of the HGCRA and its implementation as paragraph 23(2) of the SCC, which states

The decision of the adjudicator shall be binding on the parties, and they shall comply with it until the dispute is finally determined by legal proceedings, by arbitration (if the contract provides for arbitration or the parties otherwise agree to arbitration) or by agreement between the parties.

On the strength of these provisions, he accepted the claimant's argument that there is an implied term that a party who complies with the decision of an adjudicator is entitled to have the dispute finally determined by legal proceedings and to a refund if the final determination is in his favour. The judge also determined that the cause of action in such proceedings is the implied term, which accrues only when the unsuccessful party in the adjudication complies with the decision. Ennis was therefore entitled to bring the legal proceedings within 6 years from the date of payment.

The claimant, in the alternative, argued that it was entitled to the refund in restitution. Having already decided that the claimant had a cause of action under the implied term, the judge did not have to address this argument but he accepted it with only brief comments. 
In Aspect Contracts (Asbestos) Ltd v. Higgins Construction Plc [2013b] the claimant (the unsuccessful party in the adjudication) had been engaged by the defendant contractor in 2004 to carry out an asbestos survey. The contract had no provision for adjudication and, therefore, the SCC applied. The contractor contended that the claimant's inadequate survey had caused delays, for which it had suffered loss. The adjudicator to whom the disputed claim for $£ 822482.67$ was referred in 2009 decided that Aspect was liable and ordered payment of $£ 658017$.

Aspect paid the amount ordered and, in reliance on the analysis in Ennis v. Premier, brought proceedings in 2012 (more than 6 years after completion of the survey, which was alleged to have been flawed), seeking final determination of the dispute and repayment of the amount paid in compliance with the adjudicator's decision. Aspect asserted an entitlement to repayment as an implied term or in restitution. Higgins counterclaimed the balance between the amount claimed in the adjudication and that ordered by the adjudicator.

Akenhead $\mathbf{J}$ adopted a different approach in his analysis to decide preliminary issues concerning the mechanism for recovery of payment made pursuant to an adjudicator's decision. After a review of the authorities on implication terms generally, he rejected the case for implication of the repayment term. In his opinion, the case for an implied term was not supported by the authorities. In particular, he stated that such implication was unnecessary because Aspect had the option of applying to the court, either on being threatened with adjudication or on delivery of the decision, for a negative declaration that it was not liable for breach of contract.

In the absence of an implied duty, Aspect's remaining case was one for a declaration that it had not been in breach of the contract for the asbestos survey. The judge stated that the underlying cause of action in not only this claim but also Higgins's counterclaim was the alleged breach of contract for the asbestos survey. He therefore concluded that both were statute-barred.

The Court of Appeal allowed an appeal by Aspect on the issue of implication of the repayment term and the right to recover the repayment in restitution. Longmore LJ, who delivered the unanimous opinion of the court, stated that it was inherent in paragraph 23(2) of the SCC that payment pursuant to an adjudicator's decision is recoverable in the event of a final determination of the dispute in favour of the responding party in the adjudication and that the implied term argued for was no more than expression in actual words of what is inherent in paragraph 23(2).

On the accrual of the cause of action for repayment, he stated that it was the date of payment pursuant to the adjudicator's decision since the losing party in the adjudication does become entitled to the repayment until he has made the payment ordered. However, the court agreed that the defendant's counterclaim was statute- barred as decided in the TCC. The restitution issued was not argued and, therefore, received no appellate comment.

In Walker Construction (UK) Ltd v. Quayside Homes Ltd [2014], a differently constituted Court of Appeal approved the analysis of Akenhead $\mathrm{J}$ without qualification and rejected that of HHJ Stephen Davies QC in Ennis v. Premier. The doctrine of precedent required the latter court to have followed the earlier Court of Appeal's decision in Aspect v. Higgins, but this authority had not been drawn to the attention of the subsequent court.

The questions concerning the legal basis of recovery of payment made pursuant to an adjudicator's decision by subsequent legal proceedings and the applicable limitation period came before the Supreme Court as an appeal against the Court of Appeal's decision in Aspect Contracts (Asbestos) Ltd v. Higgins Construction Plc [2015]. Adopting an analysis along the same lines as that of Longmore LJ, the court dismissed the appeal by unanimous decision. As to be expected, the court also overruled all conflicting statements in Walker v. Quayside.

The current position may therefore be summarised as follows. While the responding party to an adjudication has up to the applicable limitation period after the adjudicator's decision to start proceedings towards recovery of any payment made pursuant the adjudicator's decision, the successful referring party's right to bring proceedings before the final tribunal for an improved outcome would be statute-barred after the expiry of the limitation period applicable to the original claim in the adjudication.

Although few would question the underlying legal analysis, many in the construction industry are likely to find this position unsatisfactory in two ways and, therefore, call for appropriate amendments to the adjudication legislation and the relevant industry standard forms of contract: $(a)$ the final resolution of a claim could therefore take up to 12 or 24 years depending on whether the contract had been executed as a simple contract or a deed and $(b)$ it is unacceptably one sided.

\section{Price and time impact of change events under the ECC}

Traditional contracts provide for variations across three different clauses dealing with different aspects of their impact on costs and time. For example, under the JCT2011, the value of any additional/substituted work in a variation is determined by the application of rules specified in section 5 to the prices and rates in the contract to determine the consequent increase or reduction in the contract price.

The impact of the same variation on cost from delay and disruption resulting from it is assessed as 'loss and/or expense' in section 4 (under clause 4.23) based on actual cost incurred, while the impact on the completion date is assessed as extension of time as provided for in section 2 (under clauses 2.27-2.9). Such assessment is based on actual delay suffered. 
Under the NEC3 ECC all compensation events are to be processed in the same way and in accordance with common provisions in the contract: clause 61 for notification of the events; clause 62 for quotations for the events; clause 63 on the approach and methods to be used by both the contractor and the project manager in assessing the impact of any compensation event; clause 64 on circumstances in which the project manager may make binding assessments and clause 65 on implementation of assessments.

The contract provides a clear timetable for dealing with a notified compensation event. The project manager must respond to a contractor's notification of a compensation event not later than a week after the notice (clause 61.4). If the decision is that the prices, the completion date or a key date is to be changed to reflect the impact of the notified event, the contractor should be so informed and instructed to submit quotations, which are assessments of the impact of the event in accordance with clause 63.

Otherwise, the contractor is to be informed that, for any of the applicable reasons given in clause 61.4, there is no entitlement to any change. A dispute may therefore arise at this point and would be best dealt with by a reference to the adjudicator if the matter cannot be resolved amicably. The project manager's failure to respond may be escalated by the contractor as acceptance of the compensation event and an instruction to submit quotations.

The contractor is generally obliged to submit the quotations within 3 weeks of being instructed to do so (clause 62.3). The project manager is under an obligation to reply within 2 weeks. Here too, there is a timetable for the contractor to escalate any failure to reply into deemed acceptance of the relevant quotations. In both types of the project manager's failures to act, the employer may intervene by a reference to the adjudicator, but the reasons for the project manager's failure to respond are likely to present obstacles against the employer's appreciation of the need for such intervention and ability to do so effectively.

For purposes of determining responsibility, as between the project manager and the contractor for notifying them, compensation events can be classified into two categories. First, there are those compensation events "which arise from the project manager or the supervisor giving an instruction, issuing a certificate, changing an earlier decision or correcting an assumption'. This category is referred to in this paper as category 1 compensation events.

Examples of category 1 compensation events include a project manager's instruction changing the works information (clause 60.1(1)); a project manager's instruction stopping work or changing a key date (clause 60.1(4)); and a project manager's instruction on antiquities and objects of historical value (clause 60.1(7)). The primary obligation for notifying this category is on the project manager. However, from the first sentence in clause
61.3 , the contractor also bears independent responsibility to notify such events but only where the project manager fails to discharge the primary obligation.

Category 2 compensation events are those not arising from instructions, certificates and changes of previous decisions or corrections to assumptions by the project manager or the supervisor. The contractor is under a duty to notify the project manager of any of these events that has occurred or which he expects to occur if he believes it to be a compensation event and the project manager has not already notified it (clause 61.3). The contractor bears sole responsibility for notifying category 2 compensation events. A time-bar of 8 weeks applies from when the contractor became aware of the actual or prospective occurrence of a category 2 compensation event.

According to the second sentence in clause 61.3, the consequence of non-compliance is that there is no entitlement to additional payment or extension of time for that event. This time-bar provision has acquired notoriety on account of extensive commentary from commentators (Eggleston, 2006; Gould, 2015; Lal, 2007; LLoyd, 2008; Rowlinson 2011; Thomas, 2012). A particular concern is the subjective nature of the test of awareness, a contrast to the more common objective formulations in other forms of contract. For example, clause 20.1 of the Fidic Red Book requires notice of a claim 'as soon as practicable, and not later than 28 days after the Contractor became aware, or should have become aware, of the event or circumstance' giving rise to it.

There is also the proviso that the time-bar does not apply to category 1 compensation events. In this category are to be found some of the most contentious change events that constitute common sources of disputes. For example, variations (changes of works information in NEC terminology), which are widely acknowledged as the most common cause of disputes that result in formal resolution proceedings, are not covered by the time-bar. The only barriers under the contract to the contractor, many years after the defects certificate, raising identified work as changes to the works information that should have been but were not notified as compensation events by the project manager, are clause 61.7 and the duties to act in a spirit of trust and co-operation (clause 10.1) and to serve early warning notices (clause 16.1).

Under clause 61.7 no compensation event is to be notified after the defects date, while under clause 63.4 the contractor's entitlement to additional payment and time is limited to the outcomes of the compensation event procedures. Clause 60.1(18) is a sweep-up compensation event covering any breach of contract by the employer not amounting to any of the specific compensation events under clause 60.1. It is therefore clear that the intended effect of these clauses read together is that the contractor should not be able, after the defects date, to bring up new claims for additional payment and time. Many cases, such as 
Modern Engineering (Bristol) Ltd v. Gilbert Ash (Northern) Ltd [1974], put a high clarity threshold on contractual exclusion of common law rights. Whether these provisions are effective to exclude the contractor's claims at common law has been doubted (Eggleston, 2006; Thomas 2012).

The compensation event procedures constitute easily the most criticised feature of the ECC. A practitioner commentator lamented that their multiplicity, complexity and demands are of such a magnitude that he had never been involved in a project on which they had been followed by either party (Williamson, 2007). This experience is consistent with comments on inadequate compliance with the programming obligations as the proper operation of the compensation event procedures requires an accepted programme that is up to date.

It has been reported that on some projects contractors and project managers operate simplified procedures instead (Eggleston, 2006; Rowlinson, 2011). This practice is corroborated in the case law (for examples, see RBG Ltd v. SGL Carbon Fibers Ltd [2010]; McAlpine PPS Pipeline Systems Joint Venture v. Transco Plc [2004]). On the other hand, many users are able to manage within the compensation event procedures, with or without agreed simplifications, to achieve financial closure within acceptable times after project completion (Broome, 2012; Rowlinson, 2011).

\section{Valuations and certification for payment under the ECC}

Section 50 and clause $\mathrm{Y}(\mathrm{UK}) 2$ together provide the mechanism for calculating the amount due as interim payment as well as the timetable for not only the making of the payment but also the necessary procedures to be complied with by the project manager, the supervisor and the parties. The project manager is to make periodic assessment of payment that will become due at various assessments dates (clause 50.1). The period between successive assessment dates, referred to in the contract as the assessment interval, is stated in the contract data.

The first assessment date is to be fixed by the project manager in consultation with the parties to fall within the assessment interval after the starting date stated in the contract data. Subsequent assessment dates are to occur at the end of an assessment interval after each assessment date. The date of achievement of completion is also to be treated as an assessment date even if it does not coincide with any of the assessment dates propagated automatically from the first assessment date. The date of issue of the defects certificate is the last assessment date.

Clause 50.2 outlines how the amount due at an assessment date is to be calculated. It requires calculation of not only the amount for each of two elements but also their aggregate: $(a)$ the price of work done to date (PWDD) and (b) other amounts payable to the contractor under the contract. From this aggregate, the total of amounts to be paid by the contractor or retained by the employer under the contract is to be deducted.
The relevant sums to be deducted are in respect of sanction against the contractor's failure to submit a first programme; delay damages; instalment of advanced payment repaid by the contractor; the project manager's assessment of the costs of defects listed in the defects certificate; retention (if option X16 applies); and low performance damages (if option X17 applies). Each of the listed elements has a myriad of sub-elements that require considerable cost engineering competence to quantify with a reasonable degree of accuracy. For example, every compensation event for which the project manager has either accepted quotations or made an assessment must be a sub-element.

The last paragraph of clause 50.2 states that "Any tax which the law requires the Employer to pay to the Contractor is included in the amount due'. It has been questioned whether the effect of this provision is that the elements of the PWDD include tax or that an addition is to be made to it for tax (Thomas, 2012).

Clause Y2.2 provides that the payment due date for an assessment is $7 \mathrm{~d}$ after the relevant assessment date, while clause 51.1 requires the project manager to certify the amount due within 1 week after the assessment date. The certificate is to be issued to the employer and the contractor. The first assessment of the amount due is certified. For each subsequent assessment date, the amount to be certified should be the change in the current amount due from the figure for the previous assessment date. As confirmed in RBG Ltd v. SGL Carbon Fibers Ltd [2010], a cumulative assessment of the amount due is therefore expected. It is stated in clause Y2.2 that the project manager's certificate constitutes the payment notice required to be served by section 110A(1) of HGCRA.

The final date for paying the amount due is 3 weeks after the applicable assessment date. This means that the employer must pay the amount certified by that date (clause 51.2). The employer therefore has 2 weeks after a payment certificate if the project manager certified on the seventh day after the relevant assessment date. Where the employer considers that no amount is due or a smaller amount is due, he must serve a pay less notice if he does not intend to pay the certified amount in full. This notice should state the amount the employer considers to be due and the basis on which it is calculated. The pay less notice must be served not later than $7 \mathrm{~d}$ before the final date for payment.

\section{Implications for NEC3 ECC contracts}

Possible areas of disputes in the process of notifying a compensation event and assessing and implementing the assessment include whether the notified event is a compensation event; whether the contractor caused it; whether the contractor served early warning notice; whether there is, or will be, the requisite impact; rejection of the contractor's assessment; contractor's challenge to the project manager's assessment; and employer's challenge to accepted contractor's quotations or the project manager's assessment of the event. The volume of work required and the technical complexity of some of the tasks make 
the monthly payment process a further fertile ground for disputes unless best management practice is followed and there is the expected spirit of trust and co-operation between the parties. Possible areas of dispute concerning the calculation of the amount due include whether specific work is completed without defects to justify its inclusion in the PWDD; the calculation of the elements and sub-elements of the amount due; the validity of the relevant payment notice or pay less notice in terms of its time of issue and content; and failure to make full payment on time.

It must be an implication of the philosophy of the NEC3 contracts that irreconcilable differences concerning the assessment of compensation events or payment are crystallised into disputes and referred to the adjudicator as close as possible to the completion of the relevant compensation event procedures or the issue of the relevant payment certificate. In Mears Ltd v. Shoreline Housing Partnership Ltd. [2015], Akenhead J stated that the duty to act in a spirit of mutual trust and co-operation did not imply that either party is prevented from relying on any express terms of their contract. It is arguable that the principle extends to protecting common law rights.

The key provisions through which it is sought to further the interest of early closure of claims and disputes concerning the contractor's entitlement to payment and time are the clause 61.3 time-bar on notification of compensation events; the specification of a timetable for quotations and the project manager's assessment and implementation of compensation events; the barring of notification of compensation events after the defects date (clause 61.7); the compensation event procedure as an exhaustive code for changes to the contractor's entitlements to time and money (clause 63.4); and the finality of adjudicators' decisions for which no notice of dissatisfaction is served within weeks (clause W2.4(1)). Only clauses 61.3 and W2.4(1) need any further comment.

The clause 61.3 time-bar incentivises the notification of category 2 compensation events as the contractor forfeits entitlement to additional payment or time that would otherwise be available. The contractor is under a duty to notify category 1 compensation events to the project manager but only if the latter fails to discharge the primary responsibility for notifying them.

Rejection of the contractor's assertion of a compensation event amounts to a dispute that may be referred to the adjudicator. The clause 61.3 time-bar does not apply to this category. This proposition is supported by the decision of the Court of Appeal of Northern Ireland in Northern Ireland Housing Executive v. Healthy Building (Ireland) Ltd [2014], which arose from a contract for the provision of asbestos management services by a consultant (Healthy Building (Ireland) Ltd (HBL)) to the Executive under a contract in the form of the NEC3 Professional Services Contract (PSC). That contract provides for changes to the scope of works as compensation events in terms substantially the same as the ECC. The time-bar in clause 61.3 of the ECC is replicated in the PSC. It was a term of the contract that HBL would complete surveys of buildings covered by the contract in accordance with health and safety guidance document (HSE, 2012).

The minutes of a meeting held on 10 January 2013 stated that the consultant was to take samples for analysis from every room where asbestos material may be present, a more onerous procedure than that required by the health and safety guidance HSG264. The consultant argued that the statement amounted to a change to the scope of the works required by the contract, which should have been, but was not, notified as a compensation event by the project manager, and notified it as such on 23 May 2013. The Executive rejected this assertion, maintaining that the statement was no more than clarification of the scope of services to be provided.

It further argued that, in any event, the time-bar invalidated the purported notification. On the resulting dispute being referred, the adjudicator decided that the statement was an instruction changing the scope of the works and that the time-bar did not apply as the instruction should have been notified by the project manager. Both the first instance court and the Court of Appeal agreed with the adjudicator on both issues.

Expert practitioner commentators, for example Rowlinson (2011), report reluctance of project managers to notify compensation events as a common problem on ECC projects. As already explained, the contractor has a right to notify category 1 compensation at any time up to the eve of the defects date. To a contractor stretched by staff resource demands, the temptation to withhold such notification until the very last moment when resources can be freed up to prepare quotations would be irresistible. It is also arguable that the contractor may seek common law damages as compensation where the compensation event amounts to a breach of contract by the employer.

Court or arbitration proceedings cannot be started unless the dispute has been referred to and decided by an adjudicator (clause W2.4(1)). If the tribunal is arbitration, a dispute concerning the interpretation of any clause in the contract would have to be referred first to adjudication and then to arbitration. A party dissatisfied with the arbitrator's interpretation would have to apply to the court under section 69(2) of the Arbitration Act 1996 (1996) for permission to appeal against the arbitrator's interpretation. It is only with such permission or the agreement of the other party that court proceedings on the substantive question of law may be started.

One of the criticisms of the NEC3 contracts has been that, by imposing these constraints, it is difficult for cases to get to the court, thus preventing the development of the contract with the assistance of the court (Gracia and Gracia, 2010). However, many users of the contract may see such a constraint as a positive attribute of the NEC3 contracts. 
If the unsuccessful party in an adjudication fails to serve notice of dissatisfaction with the decision within $28 \mathrm{~d}$ after the decision, it becomes finally binding (clause W2.4(2)). Fermanagh District Council v. Gibson (Banbridge) Ltd [2014] suggests that the fact that the decision has been challenged on jurisdictional grounds does not suspend time running from the date of the challenged decision. In that case the contract was in the NEC2 ECC form, which provided for the finality of adjudicators' decisions in terms materially the same as the NEC3 form. The employer failed to serve notice of dissatisfaction with an adjudicator's decision because it took the view that serving such notice would have been inconsistent with its jurisdictional challenge.

After the court had rejected its jurisdictional challenge some 4 months after the decision, it purported to serve notice of dissatisfaction with a view to referring the dispute to arbitration. The Court of Appeal of Northern Ireland held that the notice should still have been served within the stated period and that the notice served after the determination of the jurisdictional was late. The court also declined to extend time under section 12 of the Arbitration Act 1996 (1996) for the commencement of arbitration of the dispute. One of the conditions for such extension of time is that the relevant circumstances must be such as to have been outside the contemplation of the parties when they agreed to the contractual provision. In the opinion of the court, a jurisdictional challenge was not outside the contemplation of the parties as argued on behalf of the employer.

The employer's concern about possible inconsistency in serving a notice of dissatisfaction and at the same time mounting a jurisdictional challenge to the decision was not examined in any detail because of the nature of proceedings to enforce an adjudicator's decision by summary judgment. The concern must have been that such notice of dissatisfaction could have amounted to a waiver of any jurisdictional objection to the decision. These fears are not entirely without judicial authority. In Macob Civil Engineering Ltd v. Morrison Construction Ltd [1999], Dyson J (as he then was) stated that the defendant could not argue that the adjudicator's decision was void and at the same time serve notice to refer it to arbitration. The safest course of action is therefore to serve the notice of dissatisfaction but with the clearest reservation of position on the adjudicator's jurisdiction.

However, it is to be noted that, having served a timely notice of dissatisfaction with an adjudicator's decision, there is no time limit to any subsequent reference to the final tribunal other than the applicable limitation period. Legal or arbitration proceedings may therefore be started close to the expiry of the limitation period although there could be a breach of the duty to act in a spirit of trust and co-operation under clause 10.1. There has been little authority on what amounts to such a breach or what its consequences are.

As there have been very little reported empirical studies into user experience of compliance with the payment timetable and dispute resolution under the ECC, it is difficult to assess with certainty the risk the highlighted problems pose to users of that family of contracts. However, it is hardly a prudent contract policy to assume perfect ECC user behaviour and thus to ignore problems experienced on other contracts on which the provision in the ECC family could be improved.

\section{Conclusions}

Long tails of claims and disputes after project completion are a common feature on projects procured using traditional contracts. The promoters of the NEC3 contracts are highly motivated to avoid this problem and have sought to further this interest by abandoning the concept of a final certificate. Under the ECC every payment certificate is final in the sense that the determination of the amount due is not provisional as has been traditional contract practice. This approach to payment certificates has the obvious advantage of rolling final accounts, thus facilitating financial and schedule closure immediately after project completion. However, such rolling final accounting comes at the cost of increased requirements for appropriately qualified staff to produce valuations to the requisite level of accuracy within the interim payment timetable.

The clause 61.3 time-bar does not apply to compensation events 'which arise from the Project Manager or the Supervisor giving an instruction, issuing a certificate, changing an earlier decision or correcting an assumption'. This exception would not present any problem where the project manager diligently notifies such compensation events. However, there is an inevitable conflict of interest in that such notification could draw to the employer's attention any defaults in the performance of the duties of the project manager. It is therefore not surprising that some reluctance on the part of project managers to notify such events has been reported.

The contractor may therefore choose to wait until close to the defects date to comb through all project documents to identify and notify compensation events that should have been notified by the project manager. Furthermore, it is arguable that, where the relevant events amount to breach of contract by the employer, the contractor has a right to damages at common law that may be claimed at any time before expiry of the applicable limitation period.

The expectation is that any dispute concerning the assessment of a compensation event or payment is referred to adjudication. However, the contract does not specify any time limits for challenging the relevant assessment or payment certificate. Either party may therefore raise such disputes at any time within the applicable limitation period. Where a reference is made just on the eve of the expiry of the applicable limitation period, on the authority of Aspect v. Higgins, the unsuccessful party has 6-12 years after compliance with a payment order to bring proceedings before the final tribunal for recovery of the payment. 
The interest of project owners in early closure of claims and disputes concerning the contractors' payment and time entitlements cannot be overstated. It is the philosophy of the NEC3 contracts that all problems are raised and resolved contemporaneously. The growing popularity of the contracts suggests that this is done on most projects. However, there is the still the risk that the NEC3 philosophy cannot be guaranteed to be part of the culture of all parties to every NEC3 contract. Furthermore, the existence of such a culture may not always overcome pressures to abandon the philosophy when commercial survival is seriously threatened. For these reasons, the sponsors of the contracts should seriously consider additional provisions that more clearly and firmly close the door to claims and disputes long after project completion.

Such provisions should be targeted at: ensuring that the test of awareness for the purposes of the clause 61.3 time-bar is on an objective basis; providing a timetable for challenging payment issues and the related assessment of compensation events; and providing that the decision of an adjudicator becomes finally binding if the dispute decided is not referred to the tribunal within a stated period.

Any provision that limits dispute resolution by adjudication to a specified timetable would be invalidated by the HGCRA. However, the same end may be achieved by an appropriately worded conclusive evidence clause. Such a clause typically provides that, in proceedings started after a stated period, the payment certificate issued after the defects certificate is to have effect as conclusive evidence that the contractor's full entitlements under the contract or at common law have been granted. Pending action by NEC, parties to the ECC could consider such amendments by appropriate $\mathrm{Z}$ clauses.

This study raises questions concerning the extent to which the NEC's interest in achieving final financial settlement soon after the defects certificate is achieved in practice. Further research into this aspect of the ECC is therefore long overdue. Such research should be focused on $(a)$ the proportion of projects on which the payment certificate after the defects certificate effectively closes out claims and $(b)$ the user's perception of the policy of abandoning the concept of a final certificate.

\section{REFERENCES}

Arbitration Act 1996 (1996) Elizabeth II. Chapter 23. Her Majesty's Stationery Office, London, UK.

Aspect Contracts (Asbestos) Ltd v. Higgins Construction PIC [2013a] EWHC 1322 (TCC); [2013] Bus. L.R. 1199; [2013] B.L.R. 417; [2013] C.I.L.L. 3369 (first instance decision).

Aspect Contracts (Asbestos) Ltd v. Higgins Construction Plc [2013b] EWCA Civ 1541; [2014] 1 W.L.R. 1220; [2014] Bus. L.R. 367; [2014] B.L.R. 79; 151 Con. L.R. 72; [2014] C.I.L.L. 3449 (Court of Appeal).

Aspect Contracts (Asbestos) Ltd v. Higgins Construction PIC [2015] UKSC 38 (Supreme Court).
Brighton University v. Dovehouse Interiors Ltd [2014] EWHC 940 (TCC); [2014] B.L.R. 432; 153 Con. L.R. 147.

Broome J (2012) NEC3: A User's Guide, 2nd edn. ICE Publishing, London, UK.

Cubitt Building \& Interiors Ltd v. Fleetglade Ltd [2006] EWHC 3413 (TCC).

Egglestone B (2006) The NEC 3 Engineering and Construction Contract: A Commentary, 2nd edn. Wiley-Blackwell Hoboken, NJ, USA.

Fermanagh District Council v. Gibson (Banbridge) Ltd [2014] NICA 46.

Fidic (International Federation of Consulting Engineers) (1999) Conditions of Contract for Construction. Fidic, Geneva, Switzerland.

Gould N (2015) NEC Contracts: Programming, Project Management and Pricing - Have they Stood the Test of Time? Society of Construction Law, Hinckley, UK, Paper D177.

Gracia P and Gracia D (2010) Dispute resolution under NEC3 contracts: the Peter Pan conditions destined never to grow up. Arbitration 76(1): 79-85.

HMG (Her Majesty's Government) (1998a) The Scheme for Construction Contracts (England and Wales) Regulations 1998. The Stationery Office, London, UK, Statutory Instrument 1998 No. 649.

HMG (1998b) The Scheme for Construction Contracts (Scotland) Regulations 1998. The Stationery Office, London, UK, Statutory Instrument 1998 No. 687.

Housing Grants, Construction and Regeneration Act 1996 (1996) Elizabeth II. Chapter 53. Her Majesty's Stationery Office, London, UK.

HSE (Health and Safety Executive) (2012) HSG 264 - Asbestos: The Survey Guide. HSE Books, London, UK.

JCT (Joint Contracts Tribunal) (1998) Standard Form of Building Contract: With Quantities 1998. RIBA Publications Ltd, London, UK.

JCT (2005) Intermediate Building Contract with Contractor's Design (ICD). Sweet \& Maxwell, London, UK.

JCT (2011) Standard Building Contract: With Quantities 2011. Sweet \& Maxwell, London, UK.

Jim Ennis Construction Ltd v. Premier Asphalt Ltd [2009] EWHC 1906 (TCC); 125 Con. L.R. 141; [2009] 3 E.G.L.R. 7; [2009] 41 E.G. 116; [2009] C.I.L.L. 2745.

Lal H (2007) The rise and rise of 'time-bar' clauses: the 'real issue' for construction arbitrators. International Construction Law Review 24(1): 118-132.

Letang v. Cooper [1965] 1 QB 232.

Limitation Act 1980 (1980) Elizabeth II. Chapter 58. Her Majesty's Stationery Office, London, UK.

LLoyd H (2008) Some thoughts on NEC3. International Construction Law Review 25(4): 468-483.

Local Democracy, Economic Development and Construction Act 2009 (2009) Elizabeth II. Chapter 20. Her Majesty's Stationery Office, London, UK.

Macob Civil Engineering Ltd v. Morrison Construction Ltd [1999] B.L.R. 93; 64 Con. L.R. 1; [1999] 15 Const. L.J. 300. 
McAlpine PPS Pipeline Systems Joint Venture v. Transco Plc [2004] EWHC 2030 (TCC); [2004] B.L.R. 352; 96 Con. L.R. 69.

Mears Ltd v. Shoreline Housing Partnership Ltd [2015] EWHC 1396 (TCC).

Modern Engineering (Bristol) Ltd v. Gilbert Ash (Northern) Ltd [1974] A.C. 689; [1973] 3 W.L.R. 421; [1973] 3 All E.R. 195; 1 B.L.R. 73.

Mustill MJ and Boyd SC (1989) Commercial Arbitration. Butterworths, London, UK.

Ndekugri I and Russell V (2006) Disputing the existence of a dispute as a strategy for avoiding construction adjudication. Journal of Engineering, Construction and Architectural Management 13(4): 380-395.

Northern Ireland Housing Executive v. Healthy Building (Ireland) Ltd [2014] NICA 27; 153 Con. L.R. 87.
RBG Ltd v. SGL Carbon Fibers Ltd [2010] CSOH 77; [2010] B.L.R. 631.

Rowlinson M (2011) A Practical Guide to the NEC3 Engineering and Construction Contract, 3rd edn. Wiley, Hoboken, NJ, USA.

Thomas D (2012) Keating on NEC3. Sweet \& Maxwell, London, UK.

Tracy Bennett v. FMK Construction Ltd [2005] EWHC 1268 (TCC).

Walker Construction (UK) Ltd v. Quayside Homes Ltd [2014] EWCA Civ 93; [2014] 1 C.L.C. 121; [2014] B.L.R. 215; 153 Con. L.R. 26.

Williamson A (2007) The evaluation of compensation events - a practical view. In Construction Law Review 2007. Chartered Institution of Civil Engineering Surveyors, Sale, UK, pp. $47-48$.

\section{WHAT DO YOU THINK?}

To discuss this paper, please submit up to 500 words to the editor at journals@ice.org.uk. Your contribution will be forwarded to the author(s) for a reply and, if considered appropriate by the editorial panel, will be published as a discussion in a future issue of the journal.

Proceedings journals rely entirely on contributions sent in by civil engineering professionals, academics and students. Papers should be 2000-5000 words long (briefing papers should be 1000-2000 words long), with adequate illustrations and references. You can submit your paper online via www.icevirtuallibrary.com/content/journals, where you will also find detailed author guidelines. 